\title{
EDITORIAL
}

\section{PROGRESSOS NO TRATAMENTO DA MALÁRIA FALCIPARUM GRAVE}

O manuseio clínico do paciente com malária falciparum grave deve se basear no conhecimento de sua patogenia no homem. A malária cerebral é a manifestação grave mais importante da doença no homem. Não existe qualquer modelo animal adequado que reproduza as seguintes manifestações clínicas encontradas nos pacientes: coniprometimento da consciência precedendo a morte por horas ou dias, coma ou morte na ausência de anemia intensa ou altas parasitemias e recuperação rápida sem sequela neurológica na maioria dos casos. $\mathrm{Na}$ ausência de modelos animais adequados, não existe qualquer substituto para investigações clínicas de pacientes humanos capaz de elucidar os mecanismos envolvidos. Até que seja possível aumentar nosso conhecimento em relação à sua patogenia, a melhor estratégia para melhorar o manuseio da malária grave é: (1) otimizar o uso das drogas antimaláricas com o objetivo de negativar a parasitemia o mais rápido possível; (2) melhorar os cuidados gerais e de enfermagem com o objetivo de reduzir a incidência de complicações e (3) reavaliar criticamente os diferentes esquemas terapêuticos atualmente em uso.

O tratamento antimalárico deve ser iniciado assim que possível. Em pacientes gravemente enfermos a via endovenosa é a única aceitável para o início do tratamento. Em áreas de $P$. falciparum cloroquinoresistente, o cloridrato de quinino é a única droga eficaz que pode ser administrada parenteralmente. A injeção endovenosa de quinino na velocidade de cerca de $60 \mathrm{mg}$ do sal por minuto é ainda preconizada em alguns livros texto 1 , mas é potencialmente perigosa $\mathrm{e}$ pode causar altas concentrações plasmáticas de quinino durante a fase inicial de difusão da droga pelos tecidos $^{2}$. A infusão endovenosa de quinino diluido em solução isotônica aplicada durante quatro horas a cada oito horas é uma maneira segura de administrar a droga mesmo em crianças de baixa idade. A dose deverá ser sempre calculada em relação ao peso corpóreo. $\mathrm{Na}$ Tailândia, pacientes com malária cerebral freqüentemente morrem nas primeiras 48 horas após chegar ao hospital e antes que as concentrações plasmáticas de quinino alcancem altas concentrações inibitórias médias para $P$. falciparum ${ }^{3}$. A utilização de doses de ataque (o dobro da dose de manutenção) tem sido de comprovada eficácia no sentido de induzir de maneira segura concentrações plasmáticas de qui-

\section{ADVANCES IN THE MANAGEMENT OF SEVERE FALCIPARUM MALARIA}

Ideally, the clinical management of severe falciparum malaria would be based on an understanding of its pathogenesis in man. Cerebral malaria is the most important severe manifestation of the disease in man, but in this case there is no suitable animal model which reproduces the following clinical features seen in human patients: impaired consciousness preceding death by many hours or days, coma or death in the absence of profound anaemia or hyperparasitaemia and the rapid recovery without neurological sequelae of the majority of cases. In the absence of appropriate animal models, there is no substitute for clinical investigations of human patients to elucidate the underlying mechanism. Until more is known about pathogenesis, the best strategy for improving management of severe malaria is first to optimise the use of antimalarial drugs in the hope of clearing parasitaemia as quickly as possible, secondly, to improve supportive and nursing care to reduce the incidence of complications, and thirdly, to re-evaluate critically the many fashionable adjuvant therapies which are widely used.

Antimalarial treatment should be started as soon as possible. In severely ill patients, the intravenous route is the only acceptable means of initiating treatment. In the areas where $P$. falciparum is chloroquine resistant, quinine dihydrochloride is the only effective drug which can be given parenterally. Intravenous injection of quinine at a rate of about $60 \mathrm{mg}$ of the salt per minute is still advocated in some standard text books ${ }^{1}$ but is potentially dangerous as it may produce high plasma concentrations of quinine during the early distribution phase of the $\operatorname{drug}^{2}$. The intravenous infusion of quinine diluted in isotonic fluid over four hours every eight hours is a safe way of giving the drug even to small infants. The dose should always be calculated in relation to body weight. In Thailand, patients with cerebral malaria frequently die less than 48 hours after reaching hospital and before their plasma quinine concentrations have risen above the prevailingly high mean inhibitory concentrations for $P$. falciparum ${ }^{3}$. The use of a loading dose (twice the maintenance dose) has proved effective in safely achieving plasma quinine concentrations above the MIC within 24 hours of starting treatment ${ }^{4} .20 \mathrm{mg}$ per kilogram of quinine dihydrochloride was infused over four hours; subsenquently, a maintenance dose of $10 \mathrm{mg} / \mathrm{kg}$ was infused over four hours every eight 
nino acima da concentração inibitória média 24 horas após o início do tratamento. Vinte miligramas $/ \mathrm{kg}$ de cloridrato de quinino são administrados por infusão durante quatro horas; em seguida, passa-se para a dose de manutenção de $10 \mathrm{mg} / \mathrm{kg}$ durante quatro horas a cada oito horas. Este esquema não ocasionou sinais significativos de neuro ou cardiotoxicidade. Tem sido alegado $^{5}$ que em pacientes com malária falciparum grave, especialmente aqueles com insuficiência renal, as doses de ataque e de manutenção de quinino devem ser reduzidas à metade ou de $2 / 3$ e que a frequêencia da administração deve ser reduzida de oito para doze horas. Estudos farmacocinéticos em grupos de pacientes com malária falciparum com acometimento cerebral e malária não complicada, na fase aguda ou durante a convalescença, demonstraram, entretanto, que a depuração renal e a meia vida de eliminação da droga não se encontram significativamente reduzidos na malária cerebral em comparação com os casos não complicados. No grupo com malária cerebral, aqueles com insuficiência renal, apresentavam indices de depuração total e meia vida de eliminação da droga semelhante aos dos outros casos 6 . Se a dose inicial de quinino for reduzida para $5 \mathrm{mg}$ do $\mathrm{sal} / \mathrm{kg}$, as concentrações plasmáticas da droga nunca alcançariam as concentraçooes inibitórias médias prevalentes na Tailândia de cerca de $10 \mathrm{mg} /$ litro. Se no 3 o ou 4 ? dia de tratamento o paciente ainda necessita quinino parenteral, a dose deve ser reduzida de um terço para evitar posterior aumento da concentração plasmática de quinino. Em áreas como na Tailândia oriental, pode haver necessidade de se prolongar o tempo de tratamento com quinino para 10 dias e antibióticos como a tetraciclina ou eritromicina necessitem ser incluidos no esquema para prevenir a recrudescência tardia da infecção (nivel RI de resistência). A eliminação do quinino dos eritrócitos ocorre de modo muito mais rápido que do plasma em pacientes com malária cerebral $e$, conseqüentemente, não seria boa prática reduzir a freqüência do tratamento 7 .

Em alguns paises (especialmente ocidentais), a quinidina parenteral pode ser de mais fácil obtenção que o quinino parenteral, devido a seu uso no tratamento das arritmias cardiacas. A quinidina é tão eficaz quanto o quinino contra cepas cloroquino-resistentes de $P$. falciparum ${ }^{8}$. Em recente estudo o gliconato de quinidina na dose de ataque de $15 \mathrm{mg} / \mathrm{kg}$ de base, administrada por infusão durante 4 horas, seguida pela dose de manutenção de $7,5 \mathrm{mg} / \mathrm{kg}$, administrada por quatro horass a cada oito horas, apresentou comprovada eficácia e segurança quando aplicada em pacientes com malária falciparum grave (DA Warrell: dados não publicados). A quinidina é, entretanto, mais hours. This regimen was not associated with any significant cardiovascular or neurotoxicity. It has been argued $^{5}$ that in patients with severe falciparum malaria, especially those with renal failure, the initial and maintenance doses of quinine should be reduced by a half or two-thirds and that the frequency of administration should be reduced from eight hours to twelve hours. Pharmacokinetic studies in groups of patients with cerebral and uncomplicated falciparum malaria, acutely and during convalescence, have demonstrated, however, that renal clearance and elimination half time of the drug is not significantly reduced in cerebral as compared to uncomplicated cases. In the group with cerebral malaria, those with renal failure showed similar total clearances and elimination half times to the rest ${ }^{6}$. If the initial dose of quinine were reduced to $5 \mathrm{mg}$ of the salt per $\mathrm{kg}$, plasma concentrations of quinine would never rise above the prevailing MICs in Thailand of about $10 \mathrm{mg} /$ litre. If, by the third or fourth day of treatment, the patient still requires parenteral quinine, the dose should be reduced by a third to prevent further increase in plasma quinine concentration. In areas such as Eastern Thailand, the total course of quinine treatment may have to be extended to ten days, and antibiotics such as tetracycline or erythromycin added in order to prevent late recrudescence of infection (RI level of resistance). Elimination of quinine from red cells is significantly faster than from the plasma in patients with cerebral malaria, and so it would seem unwise to reduce the frequency of treatment ${ }^{7}$.

In some (especially Western) countries, parenteral quinidine may be more readily available than parenteral quinine, because of its use in the treatment of cardiac arrhythmias. Quinidine is at least as effective as quinine against chloroquine resistant $P$. falciparum $^{8}$ and in a recent study, quinidine gluconate, in a loading dose of $15 \mathrm{mg}$ of base per $\mathrm{kg}$, infused over four hours, followed by a maintenance dose of $7.5 \mathrm{mg} / \mathrm{kg}$ infused over four hours every eight hours, proved safe and effective in patients with severe falciparum malaria (Warrell et al:: unpublished). Quinidine is, however, more cardiotoxic than quinine and should be used with caution in patients with cardiac disease.

The promising new antimalarial drugs, mefloquine and halofantrine, are unlikely to be available in parenteral preparations and so their use will be limited in patients with severe disease. Mefloquine suspension given by nasogastric tube to patients with cerebral malaria was rapidly absorbed (Warrell et al.: unpublished). Various compounds extracted from the herb 
cardiotóxica que o quinino e deve ser utilizada com muito cuidado nos pacientes com cardiopatia.

É improvável que as novas e promissoras drogas antimaláricas, a mefloquina e a halofantrina, sejam apresentadas em preparações para uso parenteral e assim, terão utilização limitada em pacientes com doença grave. Suspensão de mefloquina administrada por sonda nasogástrica a pacientes com malária cerebral é rapidamente absorvida (DA Warrell: dados não publicados). Diversos compostos extraídos da erva Artemisia annua e utilizados durante séculos na China sob a denominação de "Quinghaosu" têm-se mostrado altamente eficazes no tratamento da malária cerebral. Entretanto, estas substâncias ainda não foram padronizadas nem submetidas a avaliações clínicas fora da China.

Tem sido ocasionalmente constatada a ocorrència de hipoglicemia em pacientes com malária, embora poucos casos tenham sido descritos na literatura. Um grupo de 20 pacientes foi recentemente estudado na Tailândia oriental ${ }^{10}$. Era constituído de mulheres grávidas ou no pós-parto com malária leve e por pacientes de ambos os sexos com malária grave. As manifestações clinicas usuais eram deterioração do nivel de consciência e convulsões. A maioria dos pacientes respondeu tanto ao glucagon como à dextrose a $50 \%$ endovenosa. Mostrou-se que pacientes hipoglicêmicos com malária e voluntários saudáveis recebendo infusão de quinino apresentavam altas concentrações plasmáticas de insulina, em alguns casos alcançando, ou mesmo excedendo, os niveis encontrados em pacientes com insulinomas. A secreção de insulina induzida pelo quinino parece constituir a causa mais importante de hipoglicemia em pacientes com malária falciparum mas outros mecanismos como o consumo de glicose pelo parasito - tambem devem estar presentes em alguns casos. A hipoglicemia pode ser de dificil controle porque, na presença de hiperinsulinemia, a solução de glicose administrada pode rapidamente penetrar nas células levando à hipocalemia e hipoglicemia recurrente. A hipoglicemia parece constituir complicação importante da malária falciparum, independente do tratamento com quinino. Ela pode passar despercebida e, conseqüentemente, não tratada porque o coma e outras manifestações neurológicas são falsamente interpretadas como malária cerebral. A ocorrència de hipoglicemia deve ser considerada em qualquer paciente que apresente deterioração do nivel de consciência, comportamento anormal ou desmaio, especialmente gestantes e pacientes com doença grave.
Artemisia annua and used for centuries in China under the name "Qinghaosu" have proved very effective against cerebral malaria but these substance have not yet been standardised or subjected to critical clinical testing outside China.

Hypoglycaemia has occasionally been seen in patients with falciparum malaria, but few cases have been reported in the literature. A group of 20 patients were recently studied in Eastern Thailand ${ }^{10}$. They were either pregnant or postpartum women with mild malaria, or patients of either sex with severe malaria. The usual clinical presentation was a deterioration in the level of consciousness and convulsions. Most patients responded either to glucagon or intravenous $50 \%$ dextrose. Hypoglycaemic patients with malaria and healthy volunteers given infusions of quinine were found to have elevated plasma insulin concentrations, in some cases reaching or even exceeding the levels found in patients with insulinomas. Quinine induced insulin secretion appears to be the most important cause of hypoglycaemia in patients with falciparum malaria, but other mechanisms, such as consumption of glucose by the parasites, may be involved in some cases. Hypoglycaemia may be difficult to manage because, in the presence of hyperinsulinaemia, infused glucose solution may rapidly enter the tissues leading to hypokalaemia and recurrent hypoglycaemia. Hypoglycaemia appears to be an important complication of falciparum malaria with or without quinine treatment. It may go unsuspected and untreated because coma and other neurological symptoms are misinterpreted as cerebral malaria, and should be considered in any patient with deteriorating level of consciousness, abnormal behaviour or fits, especially in pregnant patients and those with severe disease.

Of the many adjuvant treatments advocated for severe malaria over the last 30 years, corticosteroids, especially dexamethasone, have been the most popular. A double-blind placebo controlled trial of dexamethasone was carried out in 100 patients with cerebral malaria in Eastern Thailand in $1980^{3}$. Dexamethasone, given in a dose of $0.5 \mathrm{mg} / \mathrm{kg}$ initially, followed by six hourly doses of $10 \mathrm{mg}$ for the next 48 hours, failed to improve survival. $(8 / 50$ in the dexamethasone group, $9 / 50$ in the placebo group $\mathrm{p}=0.8$ ). Dexamethasone actually prolonged unconsciousness, perhaps by increasing and prolonging parasitaemia. The incidence of complications was higher in the dexamethasone treated group. This study, and its conclusions, have been criticised on the grounds that too high ${ }^{11}$ or too low ${ }^{12}$ a dose of 
Dos diferentes tratamentos coadjuvantes preconizados para a malária grave nos últimos 30 anos, os corticosteróides - e especialmente a dexametasona têm sido o de maior popularidade. Investigaçōes duplocegas controladas com dexametasona foram realizadas em 100 pacientes com malária cerebral na Tailândia oriental em $1980^{3}$. Dexametasona na dose inicial de $0,5 \mathrm{mg} / \mathrm{kg}$, seguida por doses horárias de $10 \mathrm{mg}$ pelas 48 horas seguintes, foi incapaz de melhorar a sobrevida (8/50 no grupo com dexametasona e $9 / 50$ no grupo placebo- $p=0,8$ ). A dexametasona, na realidade, prolongou o periodo de inconsciência, talvez por ter aumentado e prolongado a parasitemia. A incidência de complicações foi maior no grupo tratado com dexametasona. Este estudo, e suas conclusões, tem sido criticado com base no fato de que doses muito altas 18 ou muito baixas 12 de dexametasona teriam sido utilizadas, ou que a duração do tratamento foi inadequada, ou que os efeitos benéficos do corticosteróide seriam o de prolongar a sobrevida dos casos fatais 11 . Entretanto, até que outros estudos controlados e utilizando um grande número de pacientes sejam realizados para esclarecer estes pontos, seria aconselhável suspender a aplicação de corticosteróide nos casos de malária cerebral. Outros tratamentos coadjuvantes sugeridos incluem antiinflamatórios, agentes osmóticos, objetivando o combate a um suposto edema cerebral, dextran de baixo peso molecular, heparina, prostaciclina e adrenalina. Sua utilização em pacientes com malária se baseia em conceitos fisiopatológicos inconvincentes, sāo potencialmente perigosos e não foram ainda submetidos a controles clínicos adequados.

Tem aparecido na literatura um número crescente de casos que sugerem o efeito benéfico dramático da exsangüineo transfusão em pacientes com altas parasitemias ${ }^{13}$. Embora a troca completa de sangue seja impraticável na maioria dos paises tropicais onde a malária falciparum é mais comum, uma troca limitada de, talvez, quatro unidades de papa de hemácias frescas e compativeis constitua um procedimento racional para o tratamento de pacientes com mais de $10 \%$ de parasitemia. Na Tailândia oriental, um pequeno grupo de pacientes hiperparasitêmicos já foi tratado com sucesso por este método (DA Warrell: dados não publicados).

Os cuidados gerais e de enfermagem dos pacientes com malária grave devem incluir: (1) manter os pacientes inconscientes em posições que evitem pneumonia por aspiração; (2) o uso de anticonvulsivantes profiláticos como o fenobarbital sódico $(3,5 \mathrm{mg} / \mathrm{kg})$ administrado em uma única injeção intramuscular no dexamethasone was used, that the duration of treatment was inadequate and that a beneficial effect of corticosteroid was seen in prolonging the survival of fatal cases ${ }^{11}$. Until further large scale controlled trials have been carried out to clarify these points, however, it would seem advisable to whithhold corticosteroid sn cerebral malaria. Other suggested adjuvant treatments such as anti-inflammatory and osmotic agents aimed at combatting the putative cerebral oedema, low molecular weight dextran, heparin, prostacyclin and adrenaline are based on unconvincing concepts of pathophysiology, are potentially dangerous and have not yet been adequately tested clinically.

There is a growing literature of case reports suggesting a dramatically beneficial effect of exchange transfusion in patients with hyperparasitaemia ${ }^{13}$. Although complete exchange would be impracticable in most tropical countries where falciparum malaria is most common, a limited exchange with perhaps four units of fresh and compatible packed red cells is a rational approach to the treatment of patients with a parasitaemia of more than $10 \%$ of their red blood cells. In Eastern Thailand, a small group of hyperparasitaemic patients has so far been successfully treated in this way (Warrell et al: unpublished).

General supportive and nursing care of patients with severe malaria should concentrate on careful positioning of unconscious patients to avoid aspiration pneumonia, the use of prophylactic anti-convulsants such as phenobarbitone sodium $3.5 \mathrm{mg} / \mathrm{kg}$ given by a single intramuscular injection on admission, and maintenance of accurate fluid balance charts or daily weighing of the patient.

Some particularly serious manifestations or complications of malaria must be mentioned individually. Pulmonary oedema may be precipitated by fluid overload (excessive infusion of fluids) or may develop spontaneously, especially in hyperparasitaemic patients, in the presence of normal pulmonary artery and pulmonary wedge pressures. The latter situation resemble adult respiratory distress syndrome in which there is a primary increase in pulmonary capillary permeability. In malaria, this condition is usually rapidly fatal, but there have been some therapeutic successes achieved by sitting the patient up, giving oxygen, using potent loop diuretics such as furosemide or bumetanide and intermittent positive pressure ventilation with positive end expiratory pressure. The fear of precipitating pulmonary oedema by fluid overload may lead to undue restriction of parenteral fluid replacement resulting in renal failure in patients who 
momento da admissão e (3) controle cuidadoso do equilibrio hidrico através de anotações de ingesta $e$ excreta ou através de pesagem diária do paciente.

Algumas manifestaçōes particularmente sérias da malária ou complicações devem ser tratadas individualmente. Edema pulmonar pode ser precipitado por excesso de fluido ou pode se desenvolver espontaneamente, especialmente em pacientes com altas parasitemias, na presença de pressão normal da arteria pulmonar. Esta situação se assemelha à sindrome de insuficiência respiratoria do adulto na qual ocorre um aumento primário da permeabilidade dos capilares pulmonares. Na malária esta condição é quase sempre rapidamente fatal. Tem-se conseguido algum sucesso terapêutico mantendo-se o paciente na posição sentada, administrando oxigênio e diuréticos potentes como furosemida e bumetanida e utilizando-se ventilação com pressão positiva intermitente com pressão expiratória terminal positiva. $\mathrm{O}$ temor de precipitar edema pulmonar por excesso de liquido pode levar a uma restrição indevida na reposição parenteral de liquido, resultando em insuficiência renal em pacientes que chegam ao hospital desidratados. A avaliação das necessidades de liquidos deve se basear em dados clínicos (turgor ocular e tissular, alteração postural da pressão sangüinea, pressão venosa jugular etc.) e, se possivel, na monitorização da pressão venosa central e em acurada medida do volume urinário durante a infusão de 1 litro de solução isotônica. Em um hospital de interior da Tailandia oriental, a diálise peritoneal com duração de até 28 dias mostrou-se eficaz em pacientes que não respondiam à hidratação, diuréticos ou dopamina. Existe alguma evidência de que o "choque malárico" (malária álgida) seja resultante de complicação por septicemia por gram-negativos. Esta possibilidade deve ser considerada em pacientes com queda da pressão arterial que se apresentam com extremidades frias, úmidas e cianosadas. Insuficiència hepática na ausência de hepatite por virus e o clássico quadro de febre hemoglobinúrica (malária grave complicada com insuficiència renal e hemoglobinuria na ausência de defeito enzimático) não tem sido observado na Tailândia oriental.

\section{REFERÊNCIAS BIBLIOGRÁFICAS}

1. Adams ARD, Maegraith BG. Clinical Tropical Diseases. $6^{\text {th }}$ Edition, Oxford, Blackwell, p. 266.

2. White NJ. Chanthavanich P, Krishna S, Bunch C, Silamut K. Quinine disposition kinetics. British Journal of Clinical Pharmacology 16: 399-404, 1983. arrive in hospital dehydrated. Fluid requirements should be based on clinical assessment (ocular and tissue turgor, postural change in blood pressure, jugular venous pressure etc.) and if possible the monitoring of central venous pressure and accurate urine output during infusion of one litre of isotonic fluid. In a provincial hospital in Eastern Thailand, peritoneal dialysis, continued for up to 28 days, has proved effective in patients who fail to respond to fluid loading, diuretics or dopamine. There is some evidence that "malarial shock" (algid malaria) is the result of complicating gram negative septicaemia. This possibility should be borne in mind in patients whose blood pressures fall and who develop cold, clammy, cyanosed extremities. Hepatic failure in the absence of accompanying viral hepatitis, and classical Blackwater Fever (severe malaria complicated by renal failure and haemoglobinuria in the absence of a red cell enzyme defect) have not been observed in Eastern Thailand.

3. Warrell DA, Looareesuwan S, Warrell MJ, Kasemsarn P, Intraprasert R, Bunnag D, Harinasuta T, Dexamethasone proves deleterious in cerebral malaria: a doubleblind trial in 100 comatose patients. New England Journal of Medicine 306: 313-319, 1982.

4. White NJ, Looareesuwan S, Warrell DA, Warrell MJ, Chanthavanich P, Bunnag D, Harinasuta T. Quinine loading dose in cerebral malaria. American Journal of Tropical Medicine and Hygiene 32: 1-5, 1983.

5. Hall AP. The treatment of severe falciparum malaria. Transactions of the Royal Society of Tropical Medicine and Hygiene 71: 367-379, 1977.

6. White NJ, Looareesuwan S, Warrell DA, Warrell MJ, Bunnag D, Harinasuta T. Quinine pharmacokinetics and toxicity in cerebral and uncomplicated falciparum malaria. American Journal of Medicine 73: 564-572, 1982.

7. White NJ, Looareesuwan S, Silamut K. Red cell quinine concentrations in falciparum malaria. American Journal of Tropical Medicine and Hygiene 32: 456-60, 1983.

8. White NJ, Looareesuwan S, Warrell DA, Chongsuphajaisiddhi T, Bunnag D, Harinasuta T. Quinidine in falciparum malaria. Lancet ii: 1069-1071, 1981.

9. White NJ, Looareesuwan S, Warrell DA. Quinine and quinidine: a comparison of $E K G$ effects during treatment of malaria. Journal of Cardiovascular Pharmacology 5: 173-175, 1983.

10. White NJ, Warrell DA, Chanthavanich P, Looareesuwan S, Warrell MJ, Krishna S, Williamson DH, Turner RC. Severe hypoglycemia and hyperinsulinemia in falciparum 
Editorial. Progressos no tratamento da malária falciparum grave. David Warrell. Revista da Sociedade Brasileira de Medicina Tropical 17: 1-6, Jan-Mar, 1984

malaria. New England Journal of Medicine 309: 61-66, 1983.

11. Rees PH. Dexamethasone deleterious in cerebral malaria. Correspondence. British Medical Journal 285: 1357, $1982 ; 286: 978,1983$.
12. Hoffman SL. Dexamethasone in cerebral malaria. Correspondence. New England Journal of Medicine 307: 318, 1982.

13. Kramer SL, Campbell CC, Moncrieff RE. Fulminant Plasmodium falciparum infection treated with exchange blood transfusion. Journal of the American Medical Association 249: 244-245, 1983.

\author{
David A. Warrell \\ Director \\ Wellcome-Mahidol Unit \\ Faculty of Tropical Medicine \\ Bangkok, Thailand
}

